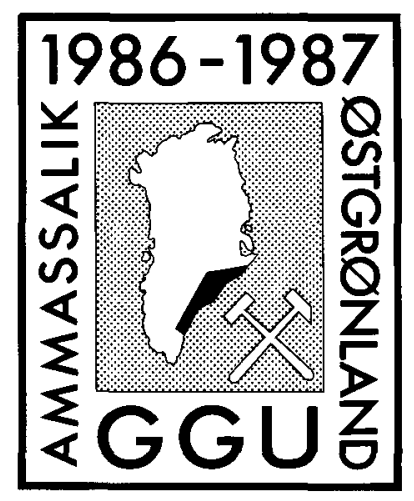

\title{
Supracrustal rocks in the Ammassalik region, South-East Greenland
}

\author{
R. P. Hall, B. Chadwick, J. C. Escher and V. N. \\ Vasudev
}

\begin{abstract}
Large belts of supracrustal rocks are abundant in the Ammassalik region of S.E. Greenland, and are referred to collectively as the Síportôq supracrustal association. They comprise overwhelmingly metasediments, mainly of quartz-rich or semipelitic composition, with variable proportions of quartz, kyanite, sillimanite, garnet and biotite. Graphitic schists are also common and marble horizons occur up to a kilometre thick. Garnet amphibolites are volumetrically minor, and ultramafic rocks are extremely rare.

Lithological banding representing relict bedding and rare cross-bedding are locally well preserved. The compositions of the metasedimentary rocks suggest that their provenance was dominantly sialic and the great thickness of semi-pelitic rocks suggests that additions of immature minerals kept pace with gentle subsidence of a basin or shelf environment. The thick marble horizons indicate periods of relative stability. Unlike the surrounding quartzo-feldspathic gneisses in the north of the area, the supracrustal rocks do not appear to have undergone granulite facies metamorphism.
\end{abstract}

\section{Introduction}

Previous mapping of coastal areas of the Ammassalik region revealed several intercalations of supracrustal rocks within the regional quartzo-feldspathic orthogneisses. Among the most notable are the garnet-rich paragneisses which envelop the Ammassalik Intrusive Complex (Friend \& Nutman, this volume), the conspicuous sheets of paragneisses and amphibolites in the Síportôq area west of Ammassalik (Palmer, 1971; Wright et al., 1973; Bridgwater et al., 1978a) and others north of Sermilik (Myers et al., 1979; unpublished GGU maps). Mapping by JCE and RPH during 1986 brought to light several new supracrustal intercalations north and west of Sermilik, whilst BC and VNV collected more details of the supracrustal suites east of Sermilik and in the Síportôq area. These new findings are outlined in this paper. The paragneisses surrounding the Ammassalik Intrusive Complex were severely modified by granulite facies metamorphism and partial melting $c$. $1850 \mathrm{Ma}$ ago (Pedersen \& Bridgwater, 1979) and most of their primary characteristics have been obliterated. Consequently, they are not considered here.

The supracrustal rocks described in this paper are part of the Síportôq supracrustal association as defined by Chadwick et al. (this volume). Correlation of supracrustal sheets throughout the region is based on similarities in lithological composition and preliminary iso- topic age data of paragneisses and marbles (Kalsbeek \& Taylor, this volume).

\section{Supracrustal rocks north and west of Ammassalik}

Sheets of the Sípertôq supracrustal association intercalated with quartzo-feldspathic orthogneisses are conspicuous and readily accessible in the Síportôq area (Chadwick \& Vasudev, this volume, fig. 12). Whilst they are relatively common between Ammassalik and 16. September Gletscher (Chadwick \& Vasudev, this volume, fig. 1), the sheets of Síportôq supracrustal rocks are here less accessible because of the severe terrain. However, good sections are accessible by boat on the coast in the interior of Angmagssalik Fjord and on the east coast of Sermilik.

Metasedimentary rocks dominate in the sheets north and west of Ammassalik. Paragneisses and schists consist of quartz, biotite, muscovite and feldspar, whilst garnet, kyanite, sillimanite and graphite are commonly abundant subordinate components. Quartz-mica gneisses with numerous small augen of feldspar form a major part of the suite in the Síportôq area. Compositional layering representing bedding is common, but other primary structures are rarely preserved. Trough cross-bedding (fig. 1) is preserved in a quartz-calciteplagioclase-microline-biotite paragneiss on a small is- 


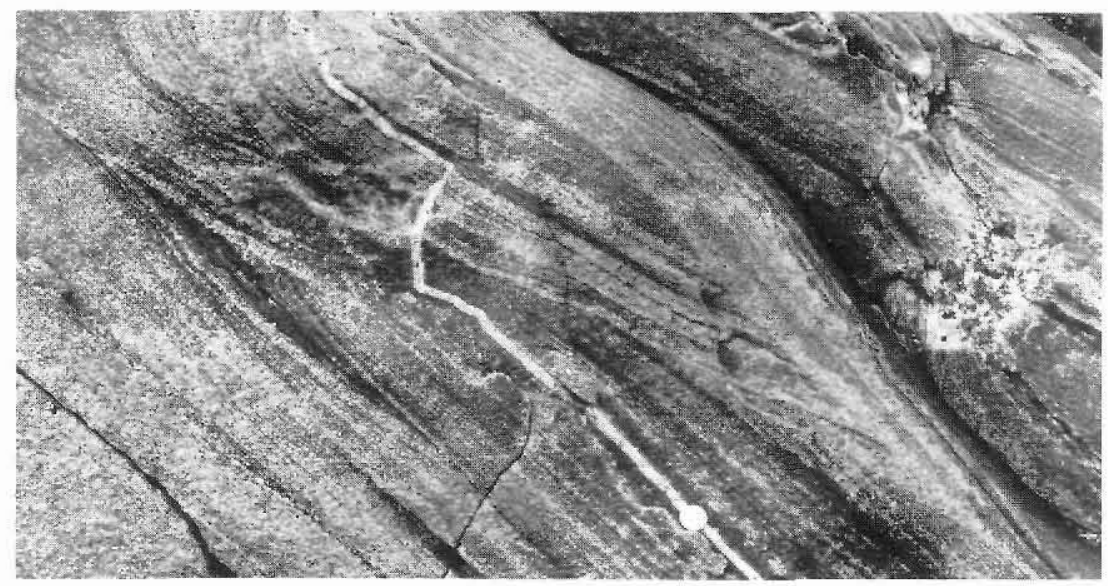

Fig. 1. Trough cross-bedding in quartz-calcite-plagioclase-microcline-biotite paragneiss, small island west of Ingmíkêrteq.

land west of Ingmikêrteq (Chadwick \& Vasudev, this volume, fig. 12). Local primary overturning of the cross-stratification may be attributed to current activity or liquefaction (Allan \& Banks, 1972; Hendry \& Stauffer, 1975).

Throughout the paragneisses and schists there are numerous thin seams rich in quartz or quartz and feldspar. Some of these seams may originally have been detrital, whilst others may have been cherts. Ferruginous garnet-rich metacherts can be distinguished in some places, but elsewhere the parents of the quartzrich seams are uncertain. Some of these seams and the biotite-quartz schists are rich in sulphides including pyrite, pyrrhotite and local chalcopyrite. Disseminated flakes of graphite are an important constituent of some sulphidic quartz-rich seams. Graphite occurs in the paragneisses and schists throughout the region, the greatest abundances having been found northeast of Rytterknægten (Chadwick \& Vasudev, this volume, fig. 1).

Carbonate-rich rocks occur locally but they do not form thick sheets like those north of Sermilik. Seams of grey graphitic marble with coarse aggregates of creamy diopside are interbedded on a scale of 1 to 2 metres with paragneisses rich in pale green diopside and heavily sericitised plagioclase at Nûk at the east coast of Sermilik and west of Solporten (Chadwick \& Vasudev this volume, fig. 1). These gneisses contain abundant accessory tourmaline. Wright et al. (1973, fig. 3) reported limestone and calc-silicate rocks in the Síportôq region, but the carbonate-bearing rocks here appear to be limited to very thin seams intercalated with laminated schists rich in diopside and green amphibole adjacent to large pods of olivine-enstatite-tremolite ultramafic rocks. These appear to be similar to the zoned bodies of sagvandite described by Wright et al. (1973).

Amphibolites are subordinate in volume to the metasedimentary component of the Síportôq supracrustal association in the Síportôq area and north of Ammassalik. They are concordantly intersheeted with the paragneisses and range in thickness from $30 \mathrm{~cm}$ to $100 \mathrm{~m}$, the thicker sheets generally being made up of a range of compositional types. Disseminated sulphides locally give rise to rusty weathering and a few amphibolites have malachite staining on joint surfaces. The most common variety of amphibolite is rich in garnet and compositionally banded. The garnet almost invariably has a reaction rim of feldspar that is commonly elongated in a tectonic pressure shadow. Paler varieties of amphibolite include feldspar-hornblende-garnet gneiss which is commonly associated with mafic amphibolite and hornblendite. Pale leucogabbroic gneisses occur in some instances. for example east of Rytterknægten (Chadwick \& Vasudev, this volume, fig. 1). Many of the thinner sheets and pods in the paragneisses are uniform amphibolite, generally without garnet. Whilst some of the amphibolites may represent lavas or tuffs, the bulk are interpreted as differentiated basaltic intrusions. Some of the sheets and pods have mineral assemblages identical to those of the amphibolite dykes in the orthogneisses.

A major body of amphibolitic breccia occurs low in the large outcrops of the association on Nûkajik headland in the south of the Síportôq area (Chadwick \& Vasudev, this volume, fig. 12). The breccia (fig. 2) is matrix-supported with unsorted lenticular fragments up to $1 \mathrm{~m}$ long by $30 \mathrm{~cm}$ wide. A few clasts are of coarse metagabbro, some are mafic amphibolite, some may be pale paragneiss, but the bulk consists largely of medium-grained feldspar. The matrix is medium-grained, dark amphibolite. The breccia is cut locally by thin. impersistent pale dykes with compositions similar to the feldspar-rich clasts. The dykes and the breccia have the same tectonic fabrics as the Síportôq association. The breccia appears to be an integral part of the Síportôq 
Fig. 2. Amphibolite breccia at Nûkajik in the Síportôq area.

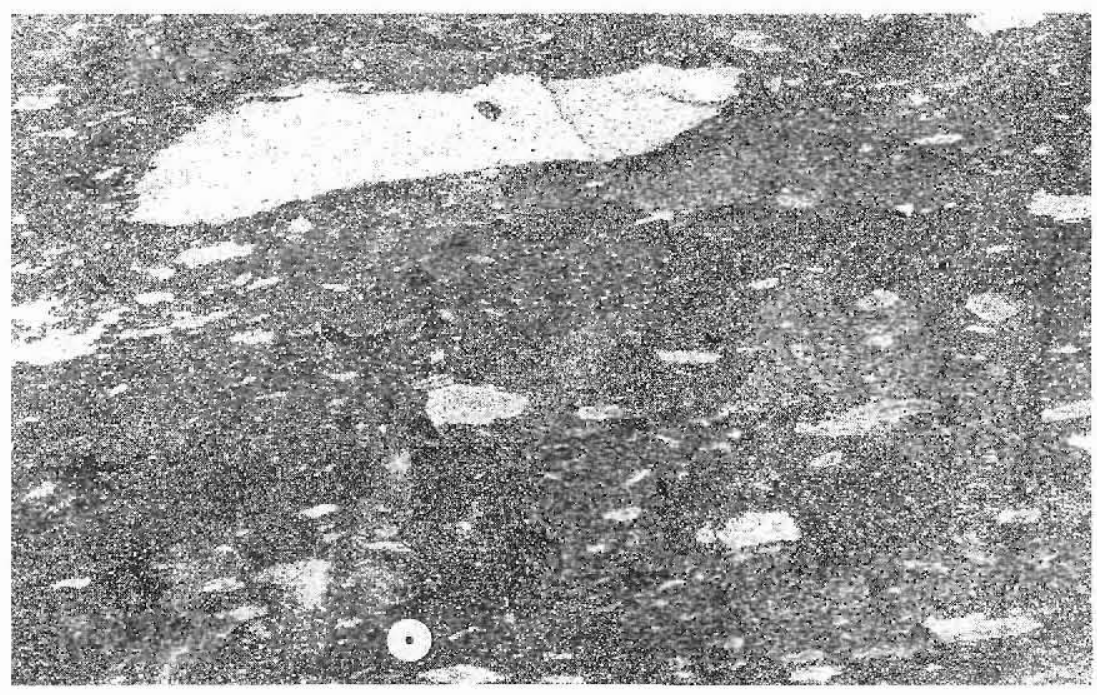

amphibolite suite and is presumed to be older than the gabbroic breccias described by Chadwick \& Vasudev (this volume). Palmer (1971, fig. 36) made brief reference to a sheared garnetiferous gneiss with inclusions of gneiss which he related to a shear zone on Nûkajik headland. We were unable to locate the shear zone or the garnetiferous gneisses. It is conceivable that the amphibolite breccias and the gneiss described by Palmer were related, perhaps as pyroclastic deposits. However, more detailed mapping is required to establish unambiguously the nature of their precursors.

Ultramafic rocks are also a minor constituent of the Síportôq supracrustal association in the Síportôq area and north of Ammassalik. They occur as pods and lenticular bodies up to $200 \mathrm{~m}$ wide and $1000 \mathrm{~m}$ long. Olivine and tremolite predominate in these rocks, commonly occurring as coarse prisms and nodular intergrowths, with subordinate green amphibole, anthophyllite, pale mica, chlorite, talc and steatite (blue-grey soapstone). In some instances orthopyroxene occurs as coarse porphyroblasts. Dunitic varieties are rare, but a large body of ultramafic rocks crops out within the orthogneisses at Ivnartivaq, south of Paornakajît (Brooks \& Stenstrop, this volume). In the Síportôq region, the ultramafic bodies commonly contain large areas of mafic, layered gabbroic amphibolite which appear to be differentiates related to their host. One of these areas of metagabbro contains translucent pink corundum, red garnet (rhodolite), brilliant blue kyanite and translucent brown tremolite, all with potential as semi-precious gemstones. The host ultramafic complex has locally sharp contacts with orthogneisses invaded by gabbroic breccias (see Chadwick \& Vasudev, this volume).

\section{Supracrustal rocks north and west of Sermilik}

A map showing the larger belts of supracrustals rocks and locality names in this region is presented by Dawes et al. (this volume - Northern boundary, fig. 3). Because of the scale of this map, no attempt has been made to distinguish the different composite lithologies of these belts. The most northerly sheets occur in the unnamed nunataks west of Juragletscheren. These are clearly more extensive than is indicated by their present restricted outcrop, which is largely hidden by the eastern edge of the Inland Ice. These nunataks will be referred to, where appropriate, by their spot heights given on the published 1:250000 scale topographic map.

The supracrustal rocks are easily recognized by their rusty-brown weathering, although several different lithologies weather to a similar colour. The limited ground investigations on these nunataks suggest that they comprise two principal lithologies. The 15 kilometre-long E-W nunatak just west of Juragletscheren has a large central zone dominated by kyanite-rich garnet-biotite paragneiss, while each end consists of greyish garnet amphibolite which is interpreted as a metadiorite. There is no field evidence which helps to determine whether this amphibolite is metavolcanic (andesitic?) or intrusive in origin. Its present homogeneous and relatively massive appearance may be due to severe recrystallization, but no relict structures suggesting a volcanic origin (modified pillow structures, lithological layering) were seen.

The same unit of leucocratic garnet amphibolite forms a large part of the largest nunatak north of Fenrisgletscher, where it is flanked by tightly folded rustybrown semi-pelitic metasediments. Similar metasedi- 


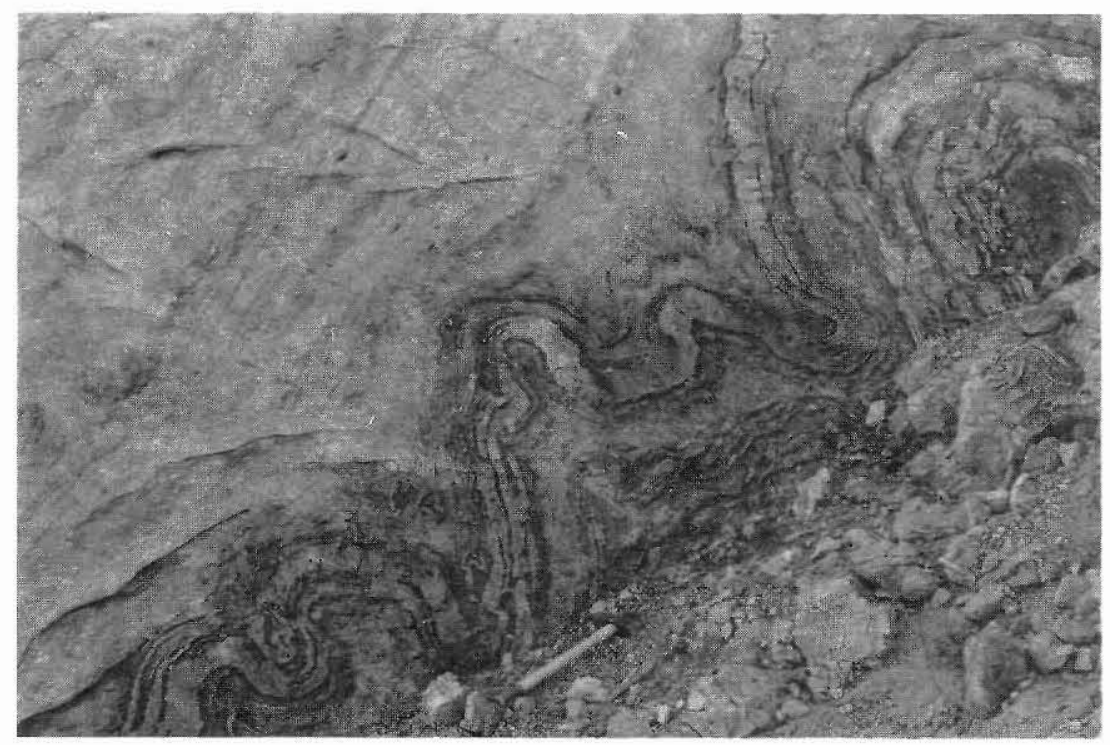

Fig. 3. Tightly folded $10 \mathrm{~cm}$ scale layers of quartzite and marble, north of Helheimfjord. The adjacent thicker marble unit is relatively undeformed.

ments overlain by amphibolites form the west cliff of the $2160 \mathrm{~m}$ nunatak to the east. They also constitute the major part of the $1680 \mathrm{~m}$ nunatak, the western cliff of which comprises amphibolite. The contact between the amphibolites which trend NNE through the middle of the $2160 \mathrm{~m}$ nunatak and the quartzo-feldspathic gneisses below is a thrust plane which dips northwestwards at approximately $40^{\circ}$. Amphibolites also dominate the $1940 \mathrm{~m}$ nunatak and contain thin sheets of rusty-weathering metasedimentary gneisses, all of which dip gently southwards and form an almost recumbent isoclinal synform, plunging shallowly to the west.

Supracrustal rocks form a series of minor belts in the Helheimgletscher - Midgårdgletscher area, just north of Sermilik (Dawes et al., this volume - Northern boundary, fig. 3). These differ slightly from those in the north in that they are lithologically more variable and commonly contain substantial amounts of marble. These marble layers vary in thickness from a few centimetres or metres, such as those on the $750 \mathrm{~m}$ and $900 \mathrm{~m}$ nunataks north and south of Helheimgletscher respectively, to several tens of metres, such as those south of Helheimfjord and south of Schweizerland, and up to a kilometre thick in the belt between Helheimfjord and Fenrisgletscher. Nearly all comprise massive, homogeneous largely calcite-rich marble with other sheets containing variable amounts of calc-silicates.

The largest marble sheet north of Helheimfjord contains layers of metaquartzite and calc-silicates (ferruginous metacherts?) interbanded on scales from a few centimetres to about one metre. Regular marble-quartzite banding is considered to reflect primary, sedimentary bedding. It is tightly folded in some localities. whereas adjacent thicker marble layers remain relatively undeformed (fig. 3). Marble constitutes approximately $50 \%$ of this belt, the remainder consisting of equal proportions of garnet-biotite ( \pm Al-silicates) paragneiss and variable, banded garnet amphibolite. The amphibolites range from mafic to leucocratic types and are banded on a metre scale, a characteristic presumed to be a reflection of the original lithological variation, although whether these amphibolites represent volcanics or an originally layered gabbroic intrusion remains uncertain. This belt comprises two isoclinal synformal structures which dip steeply westwards and close in the north, plunging moderately to the south. The cliff section on the north side of Helheimfjord reveals another synformal closure linking this belt with a disrupted, migmatized belt comprised largely of amphibolite immediately to the east. This belt has a sheared upper contact against orthogneisses.

The large SW-trending belt south of Helheimfjord also constitutes a sub-vertical isoclinal structure plunging gently southwestwards. The northern closure is defined by amphibolites which envelop rusty semi-pelitic paragneisses. Thick layers of marble occur in the core and along the southwestern limb. This belt is along strike from that on the north side of Helheimfjord. The relatively thin marble layers north and south of Helheimgletscher also occur together with rusty, semi-pelitic paragneiss and amphibolite. No marble was recognized in the larger supracrustal horizons exposed in the nunataks to the west of Helheimgletscher, which comprise mainly rusty metasediments with minor amphibolitic layers.

The two large supracrustal layers south of Schweizer- 
Fig. 4. Tectonic contact between brown weathering, retrogressed granulite facies orthogneisses (banded, pale grey) and overlying rusty-weathering predominantly metasedimentary supracrustal rocks (darker grey) in the belt south of Schweizerland (Dawes et al., this volume Northern boundary, fig. 3). Another thrust plane occurs entirely within the banded orthogneisses in the lower part of the ridge. Height of section c. $1200 \mathrm{~m}$.

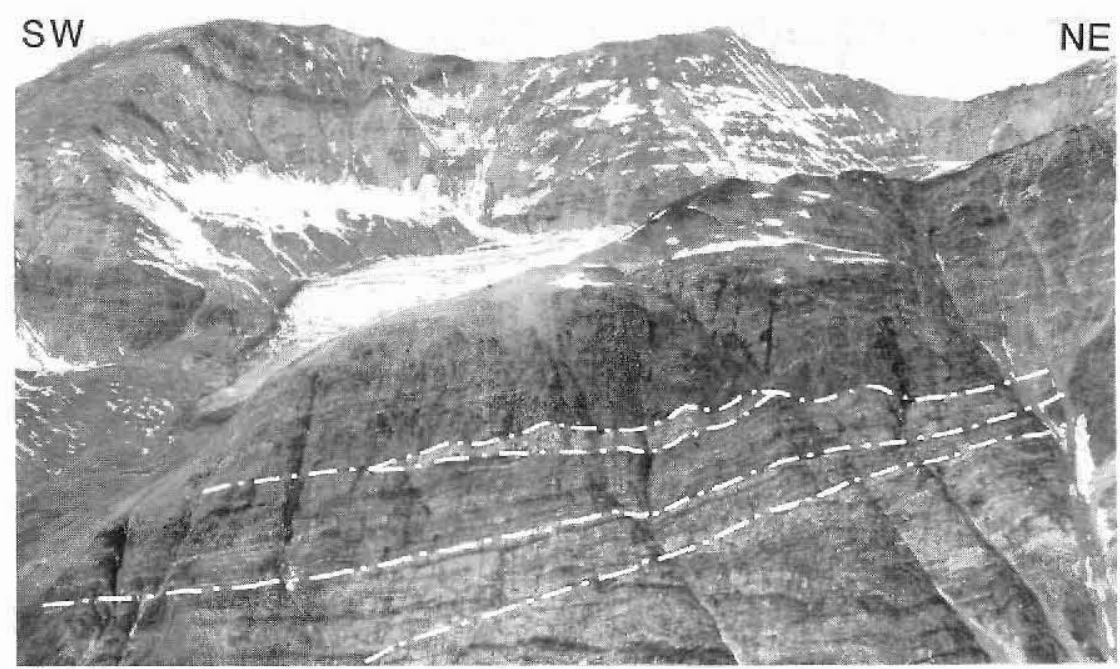

land also consist of mixtures of banded, fine and coarse garnetiferous amphibolites, minor impure marble seams ( \pm garnet), and variable quartz-rich paragneisses ( \pm biotite \pm plagioclase) and biotite-rich metapelites ( \pm garnet \pm sillimanite). Graphite-rich metasediments are abundant locally in this region. The supracrustal sheet at the south end of Charcot Fjelde, just north of Midgårdgletscher, constitutes an open synform plunging moderately southwestwards. Two thin bands of marble are interlayered on a metre scale with numerous other lithologies, clearly reflecting original fine-scale variations in sedimentary and possibly volcanic lithologies, which appear to have been only slightly disrupted during the subsequent tectonism. The belt immediately to the north comprises approximately equal proportions of fine-grained, brown-weathering, garnetiferous amphibolites and rusty paragneisses and also contains two minor bands of marble. These units are complexly folded and locally thrust contacts are clearly preserved (fig. 4).

Supracrustal rocks are also abundant to the west of Sermilik, south of $66^{\circ} 10^{\prime} \mathrm{N}$. These differ from those in the north of the region in that they contain no marble horizons and amphibolites of possible metavolcanic origin are also extremely rare. The metasediments comprise mainly variable coarse-grained garnet-biotite paragneisses in which kyanite and sillimanite are locally very abundant. Lithological variations are displayed by different modal proportions of the principal component minerals quartz, biotite, garnet, kyanite and sillimanite. Graphite-rich layers are also locally common. In one folded sheet about one hundred metres thick at Augpalugtoq on the west coast of Sermilik, coarse kyaniterich semi-pelites and finer grained garnet- and feldsparrich metasediments, rich in manganese, are repeatedly interlayered on a ten centimetre scale (fig. 5). This banding presumably reflects the original rhythmic bedding. Abundant large kyanite crystals, up to $50 \mathrm{~mm}$ long, at this locality appear to have overgrown sillimanite and define a sub-horizontal E-W mineral lineation.

Sheets of predominantly semi-pelitic paragneisses continue southwards to the island Qêrtartivatsiaq and the Johan Petersen Fjord area. In this southern region, they are modified by underlying Proterozoic granites. They develop a coarse nebulitic texture and felsic partial melt-lenses are locally abundant. These modified

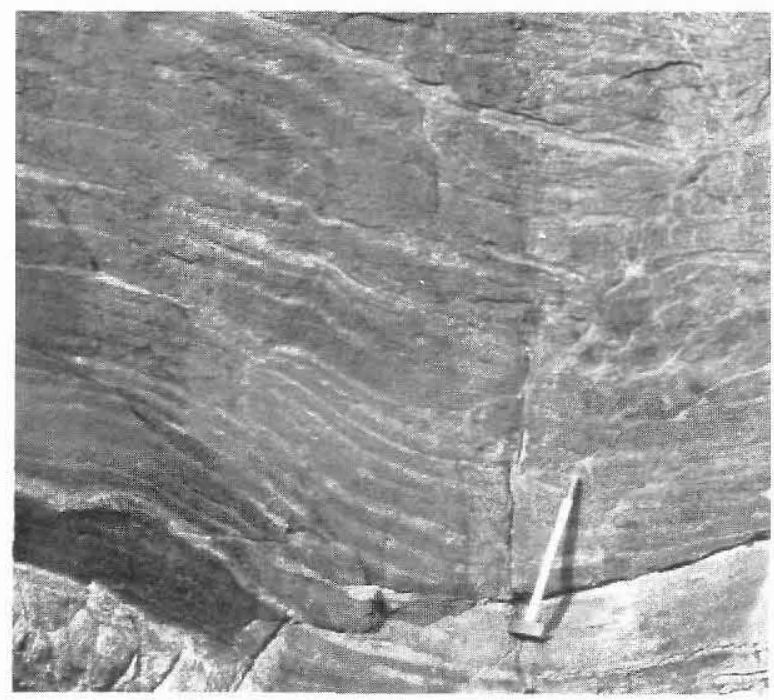

Fig. 5. Repeated $10 \mathrm{~cm}$ scale layers of garnet- and feldspar-rich metasediment (pale grey) and kyanite-rich semipelitic paragneiss (darker grey), interpreted as representing original sedimentary bedding. Augpalugtoq, west coast of Sermilik. 
paragneisses resemble some of those which surround the Ammassalik Intrusive Complex (Friend \& Nutman, this volume).

\section{Discussion and conclusions}

Large and continuous supracrustal sheets are abundant throughout the region. Those in the northernmost area comprise mixed semi-pelitic paragneisses and schists together with amphibolites which are possibly of metavolcanic origin. Those in the central zone, around Sermilik, contain the most varied assemblages including various carbonates, quartz-rich, semi-pelitic, pelitic and graphitic metasediments and garnetiferous amphibolites. Some of the marble layers are up to a kilometre thick. The southern supracrustal horizons contain only variable semi-pelitic paragneisses and schists with subordinate amphibolites and ultramafic rocks.

The compositions of the bulk of the metasedimentary rocks suggest that their original provenance was largely sialic, but whether the sediments were deposited onto a sialic foundation or an oceanic basement immediately adjacent to a continental margin is not clear from the evidence of field relationships. There is no evidence to confirm that the intercalated orthogneisses originally formed a basement as suggested by Wright et al. (1973), although indirect evidence suggests this to be the most likely case. No evidence of oceanic-type material like that in the Archaean craton of the west coast (Hall et al., 1987a) was found in the Ammassalik region.

The depositional environment of the Síportôq supracrustal association was dominated by additions of terrigenous material including quartz, feldspar and clay minerals. No conglomerates were recognised, but presence of great thicknesses of semi-pelitic gneisses within the belt suggests that gentle subsidence of perhaps a basin or a shelf environment kept pace with additions of the mixtures of immature minerals. Trough cross-bedding, albeit rarely preserved, suggests aprons of more mature calcareous feldspathic sands accummulated locally. The numerous marble horizons, particularly in the north of the region are indicative of periods of relative stability, with precipitation taking place in shallow shelf environments. The ubiquitous occurrence of graphite in the quartz-mica schists and gneisses points to the presence of a constant source of carbonaceous material, but the nature of that source remains uncertain. Thin sheets of silicate facies iron-formation occur in a few instances, but the abundance of banded iron-formation common to many Archaean and early Proterozoic supracrustal suites is not found in the Síportôq supracrustal association.

Several important features are apparent from the field observations on the Síportôq supracrustal rocks.
First, they comprise belts of very different compositions from those of the abundant supracrustal sheets within the Archaean craton of the west coast. The supracrustal belts of West Greenland are overwhelmingly of metavolcanic origin, although metasedimentary gneisses are prominent locally, for example in the Godthåbsfjord and Sukkertoppen regions (Friend \& Hall, 1977; Hall, 1978; Beech \& Chadwick, 1980). However, there are no major occurrences of marble associated with these units. The west coast Archaean metavolcanic rocks commonly preserve relict pillow structure, and they tend to be very basic, many having chemical affinities with komatiites (Hall et al., 1987a). They contrast sharply with the garnitiferous and often pale layered amphibolites of the Ammassalik region.

Inclusions of supracrustal material are frequently deformed into trains of enclaves within the Archaean orthogneisses of the west coast (e.g. Myers, 1978). Few intrusive relationships were observed between the orthogneisses and supracrustal rocks of the Ammassalik region (see Chadwick \& Vasudev, this volume), and trains of inclusions of metasedimentary rocks within the orthogneisses are rare. Amphibolite enclaves within the gneisses are commonly attributable to the disruption of basic dykes during deformation. Most of the contacts between the supracrustal belts and the adjacent orthogneisses are concordant and whilst some contacts are thrust or shear zones, the relationship between the supracrustal rocks and the orthogneisses is commonly ambiguous. Field evidence indicates that the supracrustal rocks are probably younger than most of the surrounding orthogneisses: (1) they do not occur commonly as disrupted inclusions in the orthogneisses, (2) they often preserve fine-scale lithological banding (relict sedimentary layering) where the adjacent orthogneisses are strongly deformed, (3) they show no evidence of having suffered granulite facies metamorphism like the orthogneisses north of Sermilik, and (4) discordant basic dykes are extremely rare within the supracrustal sheets but very common in adjacent orthogneisses. Moreover, the supracrustal belts of the Ammassalik region do not show close lithological affinities with the West Greenland Archaean supracrustal suites.

While there may be a few older, Archaean paragneisses present in the Ammassalik region, most of the supracrustal rocks that we mapped in 1986 are probably younger than the orthogneisses, and preliminary isotopic data suggest that they are of early Proterozoic age (Kalsbeek \& Taylor, this volume). It seems most likely that they originally formed a cover to an Archaean gneissic basement, and that the two were interleaved by thrusting and more ductile deformation during the formation of the Proterozoic mobile belt of the Ammassalik region. 